\title{
Judean Merchants in Babylonia
}

\subsection{Introduction}

According to the Hebrew Bible, Judeans in Judah and Babylonia remained in touch with each other after the deportations. ${ }^{470}$ Jeremiah 29 describes how letters were sent from Judah to Babylonia and back, and, later in Chapter 51, Jeremiah writes prophecies against Babylon on a scroll that would be sent with a Judean royal official to Babylon. Ezekiel 33:21-22 refers to a Judean refugee who brings the news about the destruction of Jerusalem to the exiles. Whatever the historicity of these accounts, it is interesting that their ancient authors took the possibility of communicating between Judah and Babylonia for granted.

Later in the first millennium CE, the exchange of thoughts, goods, and people between the Jewish communities in Palestine and Babylonia is well documented. ${ }^{471}$ These contacts were not only driven by social and religious concerns but also by commercial ambitions, and Jewish businessmen engaged in trade along the Silk Road. ${ }^{472}$ However, long-distance trade between the Eastern Mediterranean and Babylonia flourished already a millennium earlier in the Neo-Babylonian period. Babylonia had fertile soil, but it was poor in natural resources, which had to be obtained by means of tributes, taxes, and trade. Metal, wood, and luxury items were imported from different parts of the Near East, which offered opportunities for traders of non-Babylonian descent. ${ }^{473}$

The present chapter focuses on Judean merchants in Babylonia, their social networks, and their business activities. I argue that these people were integrated into the commercial sphere of Babylonian society and that they had native Babylonian merchants as well as traders of foreign origin among their acquaintances. Furthermore, because travelling and the transportation of

470 This chapter has previously been published as a journal article in Die Welt des Orients 47 (Alstola 2017). I am grateful to the publisher for the kind permission to use the article in this book. Small revisions have been made in order to accommodate it to the present study. I wish to thank the Trustees of the British Museum for their kind permission to study and cite from tablets in their care.

471 See Oppenheimer 2005, 417-432; Hezser 2011, 311-364.

472 Utas 1993, 27-28; Dignas and Winter 2007, 208-209; Hezser 2011, 325-332.

473 On Babylonian long-distance trade, see Oppenheim 1967; Graslin-Thomé 2009; Kleber 2017, 9-29. 
goods are an integral part of commercial activity, Judean merchants provide an example of people who could have maintained connections between the communities in Judah and Babylonia. The chapter begins with an overview of Babylonian trade and traders in the first millennium BCE. This is followed by a case study of the descendants of Arih, a family of Judean royal merchants in Sippar. In order to situate them in the right socio-economic context, I study the community of traders in Sippar more generally and explore the evidence of other Judean merchants in Babylonia. Finally, I discuss the role of Judean merchants in long-distance trade.

\subsection{Trade and Traders in Babylonia}

Trade in first-millennium Babylonia was not a state-monopolised business, and a diverse group of people engaged in mercantile activities. ${ }^{474}$ On the one hand, some people were explicitly identified as tamkāru ('merchant') or tamkār $(\check{s} a)$ šarri ('royal merchant'). On the other hand, urban families played a central role in local trade in agricultural staples and some even engaged in longdistance trade, although these people are never called tamkāru or tamkār šarri in the documents. ${ }^{475}$

The title tamkāru is attested in cuneiform documentation from the Old Akkadian period onwards, ${ }^{476}$ and the term was used both in the Neo-Assyrian and Neo-Babylonian periods. In the first millennium, tamkāru probably denoted the specific status of a professional merchant, but it is unclear if tamkārus were exclusively royal officials. The close connection between tamkārus and the royal administration is evident in the Neo-Assyrian period, and many tamkārus worked for the king and his high officials. ${ }^{477}$ However, Laetitia Graslin-Thomé argues that this view is skewed by the nature of the available evidence and that not all tamkärus worked for the state, as some of them could have been independent actors. ${ }^{478}$

In the Neo-Babylonian period, some tamkārus bore titles describing the type of trade they were specialised in, ${ }^{479}$ and some played a role in long-distance

474 On trade and merchants in first-millennium Babylonia, see Oppenheim 1967; Dandamayev 1995; Joannès 1999; Heltzer 2006; Graslin-Thomé 2009, 2014; Jursa 2010a, 214-228.

475 Dandamayev 1995; Jursa 2004a, 130-131; 2010a, 224-225.

476 CAD T, 125 .

477 Elat 1987; Radner 1999.

478 Graslin-Thomé 2009, 384-390.

479 Sheep and date merchants are explicitly mentioned in the archives. See Joannès 1999, 179. 
trade. ${ }^{480}$ Many luxury products - such as gold, incense, and dyes - were of foreign origin and could be obtained only via extensive trade networks covering the whole Near East. ${ }^{481}$ Tamkärus were also involved in the temple economy: they bought staples from the temple and acquired luxury products for that institution. ${ }^{482}$ In addition to tamkārus, royal merchants, tamkār $(\check{s} a)$ šarris, are attested in Babylonian sources. Even though it is clear that royal merchants were somehow affiliated with the palace, there is not enough evidence to determine whether or not they were royal officials. ${ }^{483}$ Furthermore, the terminological difference between tamkāru and tamkär šarri is not clear and the terms may have been interchangeable. ${ }^{484}$

It is important to note that tamkārus did not monopolise Babylonian domestic or long-distance trade, and people who are never identified as tamkärus engaged in various trading activities. Prosperous entrepreneurial families, such as the Egibis of Babylon and the Murašûs of Nippur, played a central role in the transportation of staples from the countryside to cities and their retail sale to urban customers. Entrepreneurs bought crops from farmers, thus providing them with a channel to sell their products and a means to pay taxes. ${ }^{485}$ Long-distance trade was only a minor interest for these wealthy families. ${ }^{486}$ Nevertheless, some Babylonian businessmen - such as Iššar-tarïbi, son of Bunene-ibni - actively participated in long-distance trade, even though they are not referred to as tamkārus. ${ }^{487}$

The existence of people like Ǐšar-tarībi, who earned his living from trade but did not bear the title of tamkāru, illustrates the complex meanings of the designations discussed above. Tamkāru was not a blanket term referring to anybody involved in domestic or long-distance trade, but it denoted rather a certain status or affiliation. As it appears that the tamkāru of the Neo-Assyrian period and the tamkār šarri of the Neo-Babylonian period were closely connected with the royal administration, it is possible that an institutional connection underlay the Neo-Babylonian term tamkāru as well. This does not

\footnotetext{
48o Dandamayev 1995, 527; Joannès 1999, 177-178.

481 Oppenheim 1967; Joannès 1999, 184-189; Graslin-Thomé 2009, 179-338; Kleber 2017, 9-29.

482 Joannès 1999, 177-178; Jursa 2010a, 580-581.

483 See Dandamayev 1995; Joannès 1999, 178; Jursa 2004a, 129-130; Heltzer 2006; GraslinThomé 2009, 397-398, 400-402.

484 Jursa 2004a, 130; 2010a, 580. However, Dandamayev 1995; Joannès 1999, 177-179; and Graslin-Thomé 2009, 401-402 take tamkāru and tamkār šarri as two different categories.

485 Stolper 1985, 27-28; Wunsch 1993 vol a, 19-55; 2007, 238-239; Jursa 2010a, 214-220.

486 Jursa 2004a, 130-131; pace Dandamayev 1995, 528.

487 On the available evidence of long-distance trade in private archives, see Jursa 2010a, 224225. On Iššar-tarībi, see Section 3.4.
} 
necessarily mean that tamkārus were dependent on the palace or temple; such an institution could be seen more as a client or, alternatively, an employer. Be this as it may, it is safe to conclude that both tamkārus and tamkār šarris were professional merchants in the Neo-Babylonian period, with the latter group being employed by the state in one way or another. ${ }^{488}$

Many merchants who engaged in long-distance trade were evidently of foreign origin, as A. Leo Oppenheim suggested already in 1967.489 Several royal merchants from the sixth century indeed bear non-Babylonian names, ${ }^{490}$ and in Nebuchadnezzar's Hofkalender the official in charge of royal merchants ( $\mathrm{rab}$ tamkārǐ ša šarri) bears the West Semitic name Hanūnu. ${ }^{491}$ The exact duties of this official are unknown, but his title and appearance among other royal officials in the Hofkalender emphasises the close connection between tamkār šarris and the royal administration. There are no other certain attestations of rab tamkārī ša šarri in Neo-Assyrian or Neo-Babylonian documents. In contrast, persons identified as rab tamkārī ('the chief of merchants') appear in Neo-Assyrian and Neo-Babylonian texts. ${ }^{492}$ It is plausible that they worked for an institution and were responsible for the management of their employer's traders or trading operations. ${ }^{493}$

\subsection{Judean Royal Merchants in Sippar}

\subsubsection{Sources}

Six cuneiform tablets pertain to the descendants of Arih, a family of Judean royal merchants in Sippar. In 1989, Martha T. Roth published a marriage agreement (BM 65149 = BMA 26) between the Judean bride Kaššãya/Amušê and the Babylonian groom Guzānu/Kiribtu/Ararru from the fifth year of Cyrus.

488 Cf. Jursa 2010a, 580.

489 Oppenheim 1967, 253-254. He is followed by Jursa 2004a, 131. On the situation in the NeoAssyrian period, see Nissinen 2014, $288+$ n. 101.

490 See Zadok 2004, 112-113; Heltzer 2006; Bloch 2014. Add also text no. 17 from the Neirabian archive (Dhorme 1928; see Tolini 2015, $84+$ n. 83).

491 Da Riva 2013, col. vi*: 18'. On the name, see Zadok 2004, 114.

492 ND 2684: 9 (Kalhu, the reign of Sargon II?, edited in Parker 1961, 43); possibly in SAA 79 obv. ii:2o' (Nineveh, the reign of Esarhaddon or Assurbanipal); CT 55 823:2 (Sippar, 21-V-13 Nbn); Camb 384:11 (Humadēšu?, 1-IX-7 Camb; for this and the following text, see Zadok 1976, 67-74); Pinches 1892a, 134: 9 (Humadēšu?, 17-X-7 [Camb]); Cameron 1948, no. 85:3 (Babylonia?, 25-IX-20 Dar); MacGinnis 1995, no. 118:6 (Sippar, 5-I-Dar).

Nbn 464:6 (Sippar, 13-X-1o Nbn) reads l' 'ial lúdam.meš [...], but Bongenaar 1997, 138-139, 406, completes the text as lígal lúdam. 〈gàr〉.meš [šá lugal]. Dandamayev 1971, 74; and Heltzer 2006, 348, understand the text similarly, but cf. MacGinnis 1994, $205+$ n. 38 .

493 See Elat 1987, 253-254; Bongenaar 1997, 138; Radner 1999, 101 n. 3. 
Another version of the marriage agreement (BM 68921), not a duplicate, was discussed by Roth in 1989 but published in full by Michael Jursa only in 2001. ${ }^{494}$ In 2007, Jursa identified an additional three tablets relating to the bride's family. ${ }^{495}$ The present author collated these three tablets (BM 68420, 74411, and 75434) in the British Museum in July 2014. Yigal Bloch added yet another tablet (CT 4 21a) to the group in his article in 2014. ${ }^{496}$ Bloch's article presents an edition of all the six tablets and a discussion of their contents and relevance for the study of Judeans in Babylonia. Because of their recent publication, there is no need to edit any texts here, but some emendations to Bloch's readings are suggested. The numbering of the tablets follows Bloch 2014.

The earliest text of the group is no. 3, written in Sippar in the tenth year of Nabonidus (BM 75434, 18-II-10 Nbn, 546 BCE). It is a promissory note for half a mina of silver, owed by the royal merchant (tamkär šarri) Basia, son of Arih, to Marduka/Bēl-īpuš/Mušēzib. Unlike his creditor, Basia is not known from other sources, and he was not a member of the urban Babylonian social stratum bearing family names. ${ }^{497}$ Judging by his patronymic, he was instead of foreign origin. ${ }^{498}$ His creditor Marduka was a well-known tithe farmer ( ̌̌a muhhi ešr $\hat{\imath}$ ) of the Ebabbar temple in Sippar. ${ }^{499}$ Because it is unlikely that the royal merchant Basia owed tithes to Marduka, the transaction was perhaps connected to the resale of agricultural produce. It is noteworthy that the tablet was written at the time of the barley harvest and repayment was to take place a month later. Professional merchants customarily bought dates from the Ebabbar temple, ${ }^{500}$ and a purchase of barley might have been behind this promissory note.

Two more tablets pertaining to the descendants of Arih were written in the eleventh and twelfth years of Nabonidus. They are similar in their contents, both referring to house rental payments and trade in gold. The more complete tablet of the two is no. 5 (BM 74411, 30-II-12 Nbn, 544 BCE), a receipt of sale which originates from the Ebabbar temple, even though the temple or the

494 Jursa 2001.

495 Jursa 2007a.

496 Bloch 2014.

497 On family names, see Section 1.5 .

498 The meaning and etymology of Arih is not clear. See Zadok 2004, 108-110; Bloch 2014, 128-129; PNA 1/I, 131. Add OIP 122 15, a sale of slaves written in Biranatu in $24 \mathrm{Nbk}\left(5^{80}\right.$ BCE), to Zadok's list of people named Arih in Babylonia (see Jursa 2006, 453-454; 2007a, n. 4). In this text, a certain Šadiku/Arih is the buyer of the slaves. Jursa 2006, 453 suggests a possible connection between this text and the text group from Sippar, but this remains hypothetical due to the lack of any other evidence than the occurrence of the name Arih.

Bongenaar 1997, 429-433; Jursa 1998a, esp. 49-52.

500 Jursa 2010a, $580-584$. 
place of writing is not explicitly mentioned. ${ }^{501}$ The transaction did not take place between two individuals; only the name of the seller of gold, Amušê/ Arih, is referred to. The purchaser remains anonymous, and neither the scribe nor the witnesses of the document are mentioned. However, the origin of the capital required for the purchase is specified in detail. The silver component was partially taken from a storehouse, part of it originated as house rental payments, and a substantial part of the price was paid in 100 kurru of dates, the equivalent of 3 minas of silver. The value of the transaction was not negligible: Amušê sold 42 shekels of gold for 5 minas and 36 shekels of silver. ${ }^{502}$ These features point towards an institutional background of the transaction, in this case the Ebabbar temple.

Text no. 4 (BM 68420, III-11 Nbn, 545 BCE) is broken, but a comparison with no. 5 helps to understand its contents. It was written in Sippar and originated in the Ebabbar administration, as the property of Šamaš is referred to on line 4. The structure of the text follows no. 5: information on house rental payments is combined with a reference to gold received from Marduka, son of Arih. A certain Marduka is also attested on line 1, but he seems to be one of the suppliers of silver and not identical to Marduka/Arih. Judging by the similarities between texts 4 and 5 , it is reasonable to suggest that no. 4 pertains to a sale of gold to Ebabbar by Marduka, son of Arih. Two points are of interest here. First, gold was a rare metal in ancient Babylonia, used solely for luxurious or cultic purposes, and silver was used as the medium of exchange. ${ }^{503}$ Second, trade in gold was the business of professional merchants, ${ }^{504}$ which strongly supports the conclusion that both Amušê and Marduka were tamkārus, if not royal merchants (tamkār šarri).

501 See Bloch 2014, 147 n. 64, 158.

502 Line 10 concerning the amount of silver is broken, which leaves some room for different interpretations. The first readable sign must be either $1 / 2$ or $5 / 6$, followed by ma.na 6 gín kù.babbar. The amount of silver is thus x minas and ${ }_{3} 6$ or 56 shekels. Line 11 reads $[a-n] a$ $5 / 6$ ma.na 2 gín kù.gi ki-i pi-i 8.kam. Accordingly, gold was exchanged for silver at a ratio of 1 to 8 . Based on the information on line 11 , Jursa (2010a, $524 \mathrm{n}$. 2856) multiplies $5^{2}$ shekels of gold by 8 , which makes 6 minas and 56 shekels of silver. However, as it appears that the origin of the silver is described on the preceding lines, Bloch $(2014,156-158)$ arrives at a different conclusion. If the broken numeral at the beginning of line 7 is 1 , the sum of the payments is 5 minas and 36 shekels of silver. Because the cuneiform signs for $2 / 3$ and $5 / 6$ closely resemble each other, Bloch suggests that $5 / 6$ minas should be taken as a scribal error for $2 / 3$ minas on line 11 . This fits the ratio of 1 to 8 ( 42 shekels of gold for 5 minas and 36 shekels of silver). Considering the transaction as a whole, Bloch's suggestion is to be followed.

503 Jursa 2010a, $474+$ n. 2584, 508, 524 .

504 Jursa 2007a. 
A number of comments on and corrections to Bloch's edition of the texts are in order here. According to Bloch, the operative part of text no. 4 continues from the obverse to the reverse and there is no witness list before the name of the scribe. ${ }^{505}$ Only the last two or three signs of the first four lines of the reverse are visible, and according to my collation of the tablet at the British $\mathrm{Mu}$ seum, they most likely present the remnants of a witness list. The beginning of the reverse can be reconstructed as follows:

8) [' ${ }^{\mathrm{l}} m u$-gin $\mathrm{PN} \mathrm{a}$ a]-šú šá

9) [PN2 a ${ }^{\text {lísanga-s]ip-parki }}$

10) $\left[\mathrm{PN}_{3}\right.$ a-šú śá $\left.{ }^{\mathrm{I}}\right] \mathrm{su}^{-\mathrm{d}}$ amar.utu ${ }^{506}$

11) [a ${ }^{\text {lí }}$ sanga-dinanna-tin.t $]$ irki507 $^{\mathrm{k}}$

12) ["úumbisag Idag?]-mu-si.sá a-šú šá

13) [ $\left.{ }^{\mathrm{I}} \mathrm{x} ?\right]-b a ?-[\mathrm{x}]$ a ${ }^{\text {lúsanga-dinanna-tin.tirki }}$

[Witnesses: $\mathrm{PN} 1$, son] of [PN2, descendant of Šangû-S]ippar; [PN3, son of] Erība-Marduk, [descendant of Šangû-Ištar-Bāb]ili. [Scribe: Nabû?]šum-līšir, son of [Balassu?], descendant of Šangû-Ištar-Bābili.

Two sequences of names with three-tier genealogies fit the available space and the remnants of the signs perfectly. Moreover, the families of Šangû-Sippar (Šangû-Šamaš) and Šangû-Ištar-Bābili played a central role among the priesthood of Ebabbar and they are frequently attested in the documentation from the temple archive. ${ }^{508}$ The person mentioned on lines 10-11 was probably one of the sons of Erība-Marduk/Marduk-zēr-ibni/Šangû-Ištar-Bābili. ${ }^{509}$ As Bloch's copy of the tablet shows, the last three signs of the personal name on line 12 are at least partially visible. The remnants of the sign before 'si.sá' suggest reading 'mu', resulting in a personal name ending with ‘šum-lišir'. From the ŠangûIštar-Bābili family, only one such man, Nabû-šum-lī̌sir/Balassu, is known to me, but reconstructing his patronymic on line 13 causes difficulties. ${ }^{510}$

505 Bloch 2014, 154-156.

506 According to Bloch 2014, 155, 'The signs at the end of 1.10 are slightly deformed'. However, instead of 'máš-šu' (Bloch 2014, 154), the signs quite clearly present the sequence 'damar. utu'.

The reading ' $\mathrm{t}] \mathrm{irk}$ ' fits the preserved signs better than Bloch's $(2014,154)$ reading ' $e$ ' $-e h$ '.

508 Zawadzki 1990, 17-25; Bongenaar 1997, 12-15, 435-463; Waerzeggers 2014a, 28-29.

509 See Bongenaar 1997, 436 with further references.

510 One sign of the patronymic is visible on line 13 . Bloch reads it as 'i', but I only see three horizontal wedges. The sign might thus be 'ba', but there is not enough space to insert 'latsu' in the break after the sign. On Nabû-šum-lǐšir/Balassu/Šangû-Ištar-Bābili, see Bongenaar 1997, 439-440. 
On line 2 in text no. 5, one should read '1 me gur zú.[lum.ma]' ('100 kurru of $\mathrm{da}[\mathrm{tes}]$ '), instead of ' 1 me gur ina gišr $b a ́ n$ " ('100 kurru by the sütu measure'). ${ }^{511}$ A reference to the type of produce makes the most sense in this context, and the price of 1.8 shekels of silver per 1 kurru of dates fits well with the range of date prices at Ebabbar in the twelfth year of Nabonidus. ${ }^{512}$ Jursa has convincingly shown that Ebabbar could not set the cost of dates independently, as market mechanisms determined the prices. ${ }^{513}$ Because the price paid for gold is also not exceptional, Bloch's conclusion that Ebabbar was 'able to bend the prices in its favour' appears to be mistaken. ${ }^{514}$ The last two signs on line 2 should perhaps be read as 'é gur' ('storehouse'). Moreover, ' $1 / 3$ gín' on line 6 is not a mistake, but a common way of referring to $1 / 3$ mina in Neo-Babylonian economic texts. ${ }^{515}$ In texts 4 and 5 , Bloch systematically translates ina qāt (ina šu ${ }^{\mathrm{II}}$ ) as 'under the charge of', referring to a commodity at someone's disposal. However, ina qāt should often be translated simply as 'from', pointing to the payer or supplier of the goods in question. ${ }^{516}$ This seems to be the correct translation, at least in no. 5 where part of the dates and silver for the purchase are supplied by Kīnā and Bakûa.

Basia and Marduka both had Babylonian names, ${ }^{517}$ but Amušê's name points to his non-Babylonian origin. A-mu-še-e is the Babylonian spelling of $H w s^{\varsigma}$ ('Hosea' or 'Hoshea'), a name which is attested several times in the Hebrew Bible. ${ }^{518}$ The significant differences in the spelling result from the characteristics of Babylonian, in which the West Semitic $h$ could not be accurately presented and $w$ was customarily written as $m$ or left completely out. ${ }^{519}$ As discussed in Section 1.5, the name Amušê was used predominantly, if not exclusively, by Judeans in Babylonia in the mid-first millennium.

\footnotetext{
511 See Jursa 2010a, 534 .

512 Jursa 2010a, 593 .

513 Jursa 2010a, 590-591.

514 Bloch 2014, 131. On the prices which the Eanna temple of Uruk paid for gold, see Joannès 1982a, 242-244.

515 Lorenz 2005/2006, 248-251.

516 CAD E, 404; CAD Q, 192.

517 Even though the etymology of both names is disputed, they are typical of the NeoBabylonian onomasticon. See PNA 1/II, 276; PNA 2/II, 704; Streck 2001, 116; Bloch 2014, 129, 153; Pearce and Wunsch 2014, 44, 65; Nielsen 2015, 58-59, 206, 208-209.

518 Zadok 1979a, 26-27; Jursa 2007a; Bloch 2014, 145-146. An alternative spelling of the name in Babylonian was Ú-še-eh (PBS 2/1 6o), for which see Stolper 1976, 26 n. 10; Zadok 1979a, 26. For some attestations of the name in the Hebrew Bible, see 2 Kgs 17-18 and Hos 1. Cf. the Neo-Assyrian attestations of this name in PNA 1/I, 238; PNA 3/II, 1421. GAG $§ 8,21,23,25$, 31. See also Coogan 1973, 189-19o; Bloch 2014, 122.
} 
Arih is a rare foreign name in Babylonian sources. It is thus striking that three sons of Arih are attested in the economic sphere of the Ebabbar temple within a period of three years. Furthermore, Basia is explicitly called a royal merchant, whereas Amušê and Marduka also appear in a context related to trade. This evidence alone may not be strong enough to confirm that the three men were brothers, but two marriage agreements corroborate their family relationship and Judean background. Bēl-uballit (son of Amušê), his unnamed brother, and their mother Gudadadìtu gave their sister and daughter Kaššāya in marriage in the fifth year of Cyrus (no. 2, BM 68921, ${ }^{520}$ II-[5 Cyr], 534 BCE). The groom was Guzānu, son of Kiribtu, whose family name of Ararru betrays his Babylonian descent. For an unknown reason, the marriage agreement of Kaššāya and Guzānu was drafted again a month later (no. 1, BM 65149, 11-III-5 Cyr). ${ }^{21}$ The witnesses had changed somewhat, but the contract remained almost the same. The only major difference seems to be the absence of the unidentified brother, who, together with his brother and mother, gave Kaššaya in marriage in no. 2. Two brothers of the bride, Šamaš-iddin and Nabû-ittannu, and a brother of the groom, Lâbâši, are among the witnesses of both documents. Amušê, the father of the bride, was absent on both occasions.

The patronymic of Amušê is not mentioned in the marriage agreements, but some of the numerous witnesses establish a link between the bride's family and the three sons of Arih discussed above. Both marriage agreements were witnessed by four royal merchants: Ahu-Yāma/Arih, Arad-Gula/Šamri-Yāma, Niqūdu/Mušallammu, and Šamaš-aplu-uṣur/Rapê. As in the previous three documents, people engaged in professional trade play a major role here. Moreover, they all have West Semitic names or patronymics, two of which are Yahwistic. ${ }^{522}$ The key person here is the first witness, Ahu-Yāma/Arih, who must have been a brother of Basia, Marduka, and Amušê. Arih is a rarely attested non-Babylonian name, but it appears four times as a patronymic of professional merchants in Sippar within a period of 12 years. This leaves little room for doubt. Accordingly, Kaššãya's father must be the same person as Amušê/ Arih in text no. 5. The Yahwistic name of Ahu-Yāma confirms the immigrant background of this family, which appears to consist of Judean royal merchants living in Sippar. ${ }^{523}$

\footnotetext{
520 The text has been previously edited in Jursa 2001. See also Roth 1989, 94-95.

521 The text has been previously edited as BMA 26. See also Jursa 2001, 2004b, 90-91. Bloch 2014, 132, suggests that the contract was drafted again because 'some difficulties arose with the marriage of Kaššaya'.

522 On Mušallammu, see Abraham 2005/2006, 216; on Rapê, see PNA 3/I, 1032-1033. On both names, see Bloch 2014, 133 .

523 For the family tree of the descendants of Arih, see Bloch 2014, 127.
} 
The three documents pertaining to Basia, Marduka, and Amušê originated in the administration of the Ebabbar temple and may thus belong to the temple archive. Alternatively, they were handed over to the merchants after the transactions were completed and the debts were paid back. ${ }^{524}$ The marriage agreements between Kaššāya and Guzānu are not related to the temple, and, together with the three other documents, they may be the remnants of the private archive of the descendants of Arih. The documents belong to the 82-918, AH 82-9-18A, and AH 83-1-18 collections of the British Museum, which are predominantly comprised of Ebabbar texts but also contain documents from private archives. ${ }^{525}$ It is likely that the private archives were unearthed together with the temple archive. ${ }^{526}$ Most of the private archives found in the vicinity of Ebabbar relate to people who held prebends and might have kept their private documents on the temple premises. ${ }^{527}$ At the same time, some private archives - such as the archive of the non-prebendary trader Iššar-tarībi - were deposited in the vicinity of the Ebabbar material because of their connection to the archive of Marduk-rēmanni. ${ }^{528}$ The main protagonist of this archive, Marduk-rēmanni, was an influential man both in the temple and in the trading communities of Sippar. The parties of the present marriage agreements belonged to the Sipparean trading community and knew people in Mardukrēmanni's circles, ${ }^{529}$ but nothing suggests that a connection to the archive of Marduk-rēmanni brought these texts into contact with the Ebabbar archive. However, the discovery of other - also non-prebendary - private archives at Ebabbar confirms that the documents pertaining to the descendants of Arih do not necessarily belong to the temple archive, but they may constitute the remnants of the private archive of the Judean family.

Even though the bride's family was of Judean origin, the marriage agreements comply with the standard features of such documents from sixthcentury Babylonia. ${ }^{530}$ As customary, the dowry given by the bride's family is described in detail: it included jewellery worth 20 shekels of silver, ${ }^{531}$ earrings

524 Promissory notes were usually handed over to the debtor when the debt was paid back; however, this was not always the case. See Jursa 2005a, 42.

525 Reade 1986, xxxiii-xxxiv; Leichty and Grayson 1987, 143, 233, 247; Leichty et al. 1988, 4, 34 (note that BM 75434 is catalogued as a receipt for a sheep); Waerzeggers 2014a, 145.

$5^{26}$ Waerzeggers 2014a, $16+$ n. 6 .

527 Bongenaar 2000, esp. 91-92. See also Jursa 2005a, 120-129; Waerzeggers 2014a, 15-22, 144-146.

$5^{28}$ Waerzeggers 2014a, esp. 19-22, 86-89.

529 See Section 3.3.2.

530 See Roth 1989; Abraham 2015, 45.

$5311 / 3$ gín šu-kut'-tu $u_{4}$. As in no. $5,1 / 3$ gín refers here most likely to $1 / 3$ mina (i.e. 20 shekels of silver). Wunsch 2003a, 4 n. 14; Jursa 2004b, 91. 
worth one shekel of gold, an Akkadian bed, five chairs, a table, a goblet, and a bronze platter. Kaššāya's family could afford to provide their daughter with some dowry, but it is noteworthy that no silver, real estate, or slaves were included. These items normally constituted the most valuable part of the dowry and were of primary interest to the husband's family, whereas jewellery, furniture, and household utensils were intended for the personal use of the bride and for housekeeping. ${ }^{532}$

The small size of the dowry may lead to two different conclusions: either Kaššayya's family could not afford to give anything else or they did not need to. The stipulations about divorce and adultery may indicate that the families of Kaššāya and Guzānu were not very wealthy. In the case of divorce, Guzānu was to pay six minas of silver and let his wife return to her paternal house. ${ }^{533}$ If Kaššãya was found with another man, she would die by the iron dagger. ${ }^{534}$ The 'iron dagger' clause is attested in marriage agreements with a small dowry or none at all, but which include a stipulation about a payment from the husband to his wife in case of divorce. According to Cornelia Wunsch, this implies that economic factors dictated the choice to include these stipulations in the marriage agreement. ${ }^{535}$ If the bride's family could afford to give a substantial dowry, the economic consequences of losing the dowry due to divorce were serious. Accordingly, no stipulations about compensatory payment were necessary. A wife's adultery must have been severely punished in these marriages as well, even though this is not made explicit in the agreements. In the marriage agreements of less wealthy people, however, clauses about a large compensation and death by the iron dagger emphasised the serious consequences of divorce and adultery.

Caroline Waerzeggers understands the social context of the iron dagger clause differently, and her interpretation fits better with the available evidence. ${ }^{536}$ She notes that the connection between poverty and the iron dagger clause is not consistent and that the clause was also used in some marriage agreements involving a dowry. The clause is never found in marriage agreements between parties who bore family names, but it is always attested in marriage agreements between parties who did not bear family names. In marriage agreements between parties from different social backgrounds, the status of the bride was decisive. If she bore a family name, the iron dagger clause was

532 Roth 1989/1990, esp. 1.

533 On divorce in Babylonian marriage agreements, see Roth 1989, 12-15; Oelsner et al. 2003, 935-936.

534 On the iron dagger clause, see Roth 1988, 186-206; Wunsch 2003a, 3-7; Waerzeggers 2016.

535 Wunsch 2003a, 3-7.

536 Waerzeggers 2016. 
not included. It thus appears that the usage of the iron dagger clause was related to the social background of the parties involved, not primarily to their wealth. In the case of Kaššāya and Guzānu, the non-Babylonian background of the bride, not her poverty, prompted the inclusion of the iron dagger clause in the marriage agreements.

Moreover, not only property was transferred in marriage. The families of the husband and bride also shared each other's prestige and social networks. ${ }^{537}$ Kaššāya's small dowry may indicate that her husband's family placed a high value on marriage ties to a family of royal merchants and that they were satisfied with a dowry consisting only of jewellery and household goods. A daughter of royal merchants was a highly prized bride, even if her family was of foreign origin. Accordingly, Kaššāya's small dowry is hardly indicative of the modest means of her family.

Before addressing the social status and networks of the descendants of Arih in more detail, two more documents have to be discussed. Text no. 6 (CT 4 21a, 5-I-19 Dar, 503 в СЕ) was drafted in Sippar 31 years after the marriage agreements. ${ }^{538}$ The document is a lease of 30 hașbattu vessels, which were probably used in a beer brewing and tavern business by the lessee Šamaš-uballiț/Nādin/ Bā'iru. ${ }^{539}$ The lessor was someone called Rìmūt/Šamaš-zēr-ibni, and the third witness was a certain Bēl-iddin/Amušê. The document belongs to the private archive of Bēl-ittannu/Šamaš-uballiț/Ša-nāšišu. ${ }^{540}$ As will be shown below, prosopographical evidence connects this document closely to the marriage agreements, and Bēl-iddin must have been a brother of Kaššāya.

A second document $(N b n$ 1) belongs to the Ebabbar archive and was written in the accession year of Nabonidus (18-III-o Nbn, 556 BCE). It is a partially broken list of people, kur.ra textiles, and small amounts of silver. The garments were most likely distributed to the workers of the temple, and the value of each garment in silver is given on the list. ${ }^{541}$ The recipients are listed without their patronymics, and a certain Amušê is mentioned on line 13. Even though he was a contemporary of the sons of Arih and attested in Sippar, he appears to have

537 The wealthy Egibis, for instance, were able to give their daughters in marriage with relatively small dowries. Becoming a member of the family was already profitable in a socioeconomic sense. See Roth 1991, 19-37.

538 BM 78391 . The tablet was acquired for the British Museum by E.A.W. Budge, and it belongs to the Bu 88-5-12 collection. See Walker 1988; Leichty et al. 1988, $15^{2}$.

539 On the connection between hașbattu vessels, beer, and taverns, see Joannès 1992; Tolini 2013.

540 The Ša-nāšišu B archive in Jursa 2005a, 126-127.

541 On kur.ra textiles and their distribution to temple personnel, see Bongenaar 1997, 39-40; Zawadzki 2010, esp. 412-414; Spar and Jursa 2014, 67. 
been a member of the temple personnel and thus different from the (royal) merchant Amušê. In any case, he was perhaps of Judean origin, given the rarity of the name and its connection with Yahwistic names in Babylonian sources.

\subsubsection{Social Network}

To have a better understanding of Kaššāya and her family of royal merchants, it is necessary to study the other people who appear in the documents discussed above. ${ }^{542}$ The extensive research done on Sipparean cuneiform documentation over the past 25 years allows me to locate the descendants of Arih and their acquaintances in a wider social context. ${ }^{543}$ However, before mapping out the social networks, it is helpful to focus briefly on the city of Sippar in the sixth century BCE.

The city of Sippar on the banks of the Euphrates was ideally located for trading purposes. The courses of the Euphrates and the Tigris were closest to one another near Sippar, and the trading routes to the Iranian plateau beyond the Tigris and to the Levant beyond the Euphrates met naturally in Sippar. In addition, the state strongly invested in the Sippar region in the sixth century ВСЕ, and royal projects created a boom in agriculture and trade. ${ }^{544}$ Consequently, a vibrant community of local businessmen, foreign traders, and royal merchants arose around the harbour of Sippar. On the other hand, Sippar was an important cult centre of the sun god Šamaš, whose temple Ebabbar stood in the middle of the city. The priests of Ebabbar formed their own closed community, and they rarely took part in trading activities as private persons, even though the temple itself traded regularly with outsiders. The communities of priests and traders can thus be seen as two distinct groups in Sipparean society. ${ }^{545}$ The international character of the Sipparean trading community is also reflected in the marriage agreements of Kaššāya and Guzānu. In addition to Amušê's brother Ahu-Yāma, three other royal merchants witnessed the marriage agreements, and they all bore West Semitic patronymics. This corroborates the wellestablished view that people of foreign origin played a key role in professional trade in Babylonia.

The descendants of Arih knew people from both the temple and the trading communities of Sippar. In their business transactions with the Ebabbar

\footnotetext{
542 Some aspects of this social network are studied in Waerzeggers 2014b, 140.

543 The most important studies for the present discussion are Bongenaar 1997; Waerzeggers 2014a. See the latter for further literature on Sippar.

544 Woods 2005, 37-40; Jursa 2010a, 64, 84-86, 322-359; Jursa and Baker 2011, 533-537; Waerzeggers 2014a, 2-4.

545 On the priests of Ebabbar, see Bongenaar 1997. Sipparean society is studied in Waerzeggers 2014a, 119-126.
} 
temple, Basia, Marduka, and Amušê came into contact with a well-known tithe farmer of the temple and with members of the most important priestly families in Sippar. ${ }^{546}$ These transactions are important in showing that merchants of Judean origin customarily traded with the temple and met people working for the institution and belonging to priestly families. However, these encounters were professional in nature, and they tell nothing about the friendship or family ties of the Judean family. When it comes to their private circles, it is more fruitful to study the people attested in the marriage agreements.

An evident point of departure for this discussion is the family of Kaššãya's husband Guzānu/Kiribtu/Ararru. The family name Ararru ('miller') is very rare in the Neo-Babylonian sources, and only seven certain attestations of the name are known to me. ${ }^{547}$ Two of these documents - namely, the present marriage agreements - come from Sippar, four from Babylon, and one probably from Babylon or Sippar. The earliest document from Babylon records the sale of an unbuilt plot in the city from the sixth year of Esarhaddon (20-v-6 Esarh, 675 BCE). The seller was Bēl-ēreš//Ararru and the buyer a certain Ea-qayališemme. ${ }^{548}$ The tablet was unearthed in the Ninurta temple in Babylon, where the Sîn-ili archive was found. ${ }^{549}$ As the tablet is older than the archive, they may be unrelated. It is also possible that the tablet was kept in the archive to record the ownership history of the plot, which was later bought by the Sîn-ilī family. 550

Two tablets from Babylon belong to the Egibi archive, the first one being a promissory note that concerns a house rental payment (Nbk 137, 21-IV-23 Nbk, $582 \mathrm{BCE}$ ). Bēl-iddin/Balassu/Ararru is listed as the second witness. The other document from the Egibi archive is also a promissory note ( $\mathrm{Nbn}$ 60o, 5-III-12 Nbn, 544 BCE), which records a debt of 23 kurru (4,140 litres) of dates to be paid back with 25 vats of good beer. The creditor was Itti-Marduk-balāțu/Nabûahhē-iddin/Egibi and the debtor Balāțu/Marduk-nāṣir/Ararru.

The fourth tablet from Babylon is a promissory note for 6 kurru of dates (VS 3 53, 4-III-11 Nbn, 545 вCE), written by a scribe called Arad-Marduk/Bēl-[...]/ Ararru. The names of the creditor and debtor are both peculiar, the former

$546 \quad$ See Section 3.3.1.

547 I am grateful to Cornelia Wunsch for her substantial help in gathering the evidence. See also CAD A/2, 233; Tallqvist 1905, 67; Wunsch 2014, 303; Nielsen 2015, 36. There are three other documents that may mention the family name Ararru: Dar 411:13 (but according to Abraham 2004 no. 119, the sign should be read as šitim, 'Itinnu'); OECT 10 295; RINAP 4126.

548 Jakob-Rost 1970 no. 4. Note that according to Jakob-Rost's translation of the broken passage, the seller was Ea-qayal-išemme and the buyer Bēl-ēreš. See Pedersén 2005a, 239.

549 Pedersén 2005a, 228-232, 239. On the Sîn-ilī archive, see Jursa 2005a, 69-71.

550 Pedersén 2005a, 228-231. 
being Nabû-ahhē-bulliț/Aššur-mutaqqin-dīn(?) and the latter Mil-ki-šu-mulugal-ùru/Ha-am-[ma?]-ta-a-a. Names containing the theophoric element A ššur are rare in Babylonia, ${ }^{551}$ and $m l k$ is not an Akkadian root but a common West Semitic one. ${ }^{552}$ If Hammatāya is the correct restoration, the patronymic means 'the Hamathean. ${ }^{553}$ The tablet cannot be assigned to any known archive. Yet another text concerning the Ararru family most likely originates from Babylon or, alternatively, from Sippar. The unpublished tablet BM 77945 (19 Nbk?, 586 вСE?) mentions PN/Aplā/Ararru among the witnesses of a lawsuit. 554

There is no prosopographical evidence to demonstrate that the descendants of Ararru were all members of a single family. However, several interesting conclusions can be drawn from the seven texts discussed above. First of all, nothing suggests that the Ararrus held prebends at Ebabbar or any other temple in Babylonia. Even though they bore a family name and thus belonged to the upper social stratum in Babylonian society, their profile appears more mercantile than priestly. ${ }^{555}$ Whereas the private life of prebendary families was turned towards the priestly in-group, ${ }^{556}$ Guzānu took a wife from a Judean family of merchants and the Ararrus of Babylon had contacts with people of nonBabylonian origin. The fact that they engaged in beer brewing and were connected to the wealthy business family of Egibi indicates that they were involved in business activities in Babylon. Finally, the Ararrus originated from Babylon rather than from Sippar. The marriage agreements of Kaššāya and Guzānu are the only certain attestation of the Ararrus in Sippar, whereas there are four or five separate documents from Babylon. This is noteworthy because several families moved from Babylon to Sippar in the sixth century, including the Șāhit-ginês, a branch of the Ša-nāšišus, and the Arad-Nergals. Royal investment and the booming economy made Sippar attractive for newcomers, some of whom achieved great success in their new hometown. Even though some members of these families were able to make their way into the priestly circles of Ebabbar, the community of newcomers was geared towards trading

\footnotetext{
$55^{1}$ See Tallqvist 1905, 16-17.

$55^{2}$ See PNA 2/II, 750-753.

553 Zadok 1977, 12, 20-21, 248.

554 Personal communication with Cornelia Wunsch. She suggests that the tablet probably originates from Babylon. Cf. Leichty et al. 1988, 121. According to Walker 1988, xi-xiv, the tablet was acquired from a private person and it possibly originates from Babylon or Sippar.

555 Cf. Bloch 2014, 145.

556 Still 2019.
} 
activities. ${ }^{557}$ It is much easier to fit the family of Guzānu into this mercantile community than into the old, established elite of Sippar and the priestly circles of Ebabbar.

Some of the witnesses with Babylonian names, patronymics, and family names can also be identified as members of the Sipparean mercantile community. The business profile of these people becomes apparent from the documents belonging to the archive of Marduk-rēmanni/Bēl-uballiț/Sāhit-ginê and its satellite archives. Marduk-rēmanni's family originated in Babylon but moved to Sippar in the sixth century, and Marduk-rēmanni became a member of the local trading community. At the same time, he succeeded in gaining a strong foothold in the priestly circles of Ebabbar, and his archive is an indispensable source of information on the life of these two distinct communities. ${ }^{558}$ Neither Marduk-rēmanni nor members of his family appear in the documents pertaining to the descendants of Arih, but they shared several common acquaintances. A witness of both marriage agreements, Nabû-iddin/ Bānia/Pahhāru, was related to two business agents of the Șāhit-ginê family.559 Another link to the Șāhit-ginê family was Bānia/Bēl-nāșir/Arad-Nergal. He belonged to a family which had moved from Babylon to Sippar at the same time as the Șāhit-ginês and had become part of the Sipparean trading community. ${ }^{560}$ Another interesting witness in the earlier marriage agreement is Šuzubu/ Zababa-ah-iddin/Ile'i-Marduk, who acted several times as a scribe in documents in Marduk-rēmanni's archive. ${ }^{561}$ Finally, a certain Guzānu/Kiribtu is a witness in a promissory note belonging to the archive of Marduk-rēmanni, and it is possible that this Guzānu was the groom of Kaššāya. ${ }^{562}$

Prosopographical data connects text no. 6 with the marriage agreements and the family of Kaššāya, even if Bēl-iddin/Amušê, the third witness of no. 6, is not attested in the marriage agreements. A direct link between the earlier marriage agreement no. 2 and text no. 6 is (Nabû-)Bān-zēri/Rīmūt-Bēl/Isinnāya, who witnessed both documents. Interestingly enough, he is the only witness of the marriage agreements to have held a prebend at the Ebabbar temple. ${ }^{563}$ The profiles of the lessee and surety in no. 6 indicate that the text originated in the same social setting as the five earlier documents. The lessor Rīmūt/Šamaš-zēribni cannot be definitively identified in other extant documents, but the lessee

\footnotetext{
557 On these families, see Waerzeggers 2014a, 45-49, 119-124.

$55^{8}$ Waerzeggers 2014a, esp. 15-30, 61-93, 113-125.

559 Waerzeggers 2014a, 81-82, 214; MR 8, 25.

56o Waerzeggers 2014a, 45-49.

$561 \quad$ MR 23, 24, 69, 85, 86, 171.

562 Waerzeggers 2014a, 214; MR 39.

563 He held a baker's prebend; see Bongenaar 1997, 173.
} 
Šamaš-uballiț/Nādin/Bā'iru participated in a harrānu business venture with a member of the Ša-nāššsu family in BM $74469 \cdot{ }^{564}$ The Ša-nāšišu family, which had also migrated to Sippar from Babylon, was a part of the Sipparean mercantile and priestly communities. ${ }^{565}$ Another member of this family, Bēl-ittannu/ Šamaš-uballiț/Ša-nāšišu, acted as a surety in text no. 6, a document which belongs to his private archive. ${ }^{566}$ Bēl-iddin/Amušê must have been familiar with these people and their businesses. It is likely that his father Amušê was the father of Kaššãya: the descendants of Arih and the lessee and surety of text no. 6 shared an interest in entrepreneurial activities, Amuše is a rare name in Babylonian sources, and a brother of Kaššāya could still have been alive 31 years after the marriage agreements were drafted. However, it is impossible to know if Bēl-iddin was the unnamed brother in the earlier marriage agreement. ${ }^{567}$

Prosopographical research shows that the descendants of Arih were closely connected with the community of merchants in the city of Sippar. As royal merchants, they traded with the Ebabbar temple, but only one of the witnesses in the marriage agreements was a priest holding a prebend. ${ }^{568}$ The family of the groom had a mercantile rather than a priestly profile, and the witnesses of the marriage agreements were predominantly royal merchants or belonged to families which participated in trading activities. The international character of Sipparean traders is also quite apparent in the texts, and people of both West Semitic and Babylonian origin were among the acquaintances of the Judean family. In this connection, it is important to note that some members of the Sipparean trading community participated in long-distance trade from Syria and the Levant to Babylonia. ${ }^{569}$ Accordingly, the family of Arih was rooted in two distinctively international realms of Babylonian society. On the one hand, they were part of the state apparatus as royal merchants; 570 on the other hand, they were members of the multi-ethnic community of traders at the quay of Sippar.

\subsubsection{Identity, Integration, and Socio-Economic Status}

Analysis of the social network of the descendants of Arih shows that the Judean family had found a place among the community of merchants in Sippar.

\footnotetext{
$564 \quad$ Jursa 2005a, $126+$ n. 968.

565 On the Ša-nāšišus, see Waerzeggers 2014a, 46, 72-74, 124-125.

566 The Ša-nāšišu B archive in Jursa 2005a, 126-127.

567 Cf. Bloch 2014, 160-161.

568 Cf. Bloch 2014, 141.

569 Bongenaar 2000, 86; Waerzeggers 2014a, 85-89.

570 See Jursa 2015 b on the multi-lingual and multi-ethnic character of the Babylonian state administration.
} 
In the following discussion, I study how this is reflected in their identity and how deeply they were integrated into Babylonian society. These questions have been studied in detail by Bloch, ${ }^{571}$ and I thus limit my discussion to some new aspects and interpretations of the evidence.

The majority of the names of the descendants of Arih are Babylonian. ${ }^{572}$ Only two of his sons, Ahu-Yāma and Amušê, had distinctively Judean names. The names borne by the third generation are fully Babylonian, and three different gods - Bēl (Marduk), Nabû, and Šamaš - are referred to in the theophoric elements. At first sight, the naming practices of this Sipparean family are in stark contrast to the figures derived from the Judean communities in the countryside. A significantly higher number of identifiable Judeans in the Murašû archive bear Yahwistic names, and the same applies to Judeans in Yāhūdu and its surroundings. ${ }^{573}$ The descendants of Arih were certainly quite different from the Judeans in the countryside, but the available data is somewhat misleading as well. Judeans can be normally identified only on the basis of Yahwistic or other distinctly Judean names possessed by them or their relatives. This skews the overall picture in favour of those who bore traditional Judean names.

The relationship between theophoric names and religious practice is complex, and a theophoric name devoted to a certain deity does not exclude its bearer's worship of other gods. Therefore, it cannot be argued that Ahu-Yāma revered Yahweh and Bēl-iddin worshipped Marduk. However, the readiness to use Babylonian theophoric names indicates that the descendants of Arih were at home in the religious environment of Babylonia. ${ }^{574}$ This is visible also in Kaššāya's and Guzānu's marriage agreements, in which Marduk, Zarpanītu, and Nabû were customarily invoked in the curse section. This is noteworthy in light of Kathleen Abraham's argument that the stipulations of a marriage agreement were negotiated by the parties and not dictated by the scribe. ${ }^{575}$ Accordingly, the invoking of Babylonian gods could not have been an abomination to the Judean family. Judean traditions are visible in the names of AhuYâma and Amušê, but Yahweh's importance for the descendants of Arih remains unknown.

\footnotetext{
571 Bloch 2014, 127-135.

572 See Bloch 2014, 127-130.

573 Section 8.5. On the Murašû archive, see Bickerman 1978, 15; Bloch 2014, 124-125. A similar picture arises when Bickerman's method is applied to the prosopographical data from Yāhūdu and its surroundings (see the prosopographical index in Pearce and Wunsch 2014, 257-300). See also Pearce 2015, 19-22, 29.

574 See Bloch 2014, 129-130.

575 Abraham 2015, 33-57.
} 
The names of the descendants of Arih reflect the environment they were living in. As members of the Sipparean trading community, they had people of Babylonian and foreign origin in their intimate circles. Close contact with Babylonians accelerated their integration and adoption of local naming practices. Their professional life as merchants naturally played a role in this process, but a desire to advance trade relations with the Ebabbar temple was hardly the main reason for it. ${ }^{576}$ Contact with Babylonians was not a decisive factor in the adoption of Babylonian names or culture, as the example of Ahīqam, son of Rapā-Yāma, from the village of Yāhūdu shows. This Judean was in close contact with Babylonians $\left(\mathrm{C}_{14}, 17,18\right)$ and even traded in Babylon $\left(\mathrm{C}_{44}, 45\right)$, but he did not give Babylonian names to his sons. ${ }^{577}$ The nature and intensity of contact were likely important, as collegial and friendship ties are often more influential than business relationships. ${ }^{578}$

Several aspects of Kaššāya's marriage agreements exhibit a high level of integration into Babylonian society. These include her marriage into a Babylonian family, the Babylonian witnesses of the contract, and its conformity to the standard legal practices of its time. An interesting detail of the dowry is the Akkadian bed (gišná $a k-k a-d i-i-t u_{4}$ ), which stands out from the list of jewellery, furniture, and household utensils. Kaššayya is one of three brides in Neo-Babylonian sources who received such a bed as a part of their dowry. ${ }^{579}$ Another bride, Habašinnatu (Nbn 258), came from the Kāṣir family and married into the Rab-banê family; in her case, the Akkadian bed was one of four beds given as a dowry. The family names confirm that the marriage was established between native Babylonians. A third bride, Tahê-[...], not only received an Akkadian bed but also an Akkadian table, according to the marriage agreement BMA 23 (= Dar 301). Both Tahê-[...] and her husband Pațmiustû were of Egyptian origin, ${ }^{580}$ which makes this case comparable to the marriage agreement of Kaššaya. Even though the nature of an Akkadian bed is unknown, it must have been somehow different from the ordinary beds of the period. ${ }^{581}$ It is tempting to perceive the Akkadian bed as a device which these two immigrant families used to emphasise their integration into Babylonian society. ${ }^{582}$ The Akkadian

576 Cf. Bloch 2014, 132.

577 See Section 4.3.6.3 and Ahīqam's family tree in Pearce and Wunsch 2014, 8.

578 This relates to the concept of tie strength in social network analysis. See Granovetter 1973, 1360-1380.

579 See Roth 1989/1990, 21-22; CAD E, 317.

580 Abraham 2015, 40-44; Hackl and Jursa 2015, 162-163, 165 .

581 This is made clear in Nbn 258:8-9. In addition to the three dowries, an Akkadian bed is also included in a list of furniture and household utensils in Nbk 441:1.

582 Personal communication with Caroline Waerzeggers. 
bed was a product of their new homeland and thus loaded with symbolic value, not a mere piece of furniture.

The previous observations about their integration, social networks, and status as royal merchants indicate that the descendants of Arih had a relatively good social standing in Sippar. Intuitively, one would like to suggest that professional merchants like the family of Arih were wealthy, but the scanty information on their possessions does not allow easy conclusions. First, the transactions of Basia, Marduka, and Amušê are silent on the profits which the brothers made from their trade. Only the marriage agreements reveal something about the wealth of the family, but, as noted above, the picture is somewhat unclear. The bride indeed received some jewellery for personal use and furniture and kitchen utensils for running the new household, but the dowry lacked any truly valuable items such as silver, real estate, or slaves. However, a modest dowry was not always indicative of financial constraints, and it cannot be reliably used to estimate the wealth of the bride's family. Given their profession, social networks, and success in marrying their daughter to a man from the Ararru family, the descendants of Arih belonged to the better-off segment of Babylonian society. .83

\subsection{Other Judean Merchants in Babylonia}

In addition to the descendants of Arih, three other Judeans were involved in trading activities in Babylonia in the sixth century вСЕ. The documents concerning these people relate to long-distance trade, which helps to contextualise the transactions of the Judean royal merchants in Sippar. The earliest attestation of a Judean trader in Babylonia is dated in the fortieth year of Nebuchadnezzar II (21-IV-40 Nbk, 565 BCE). The document was written in Opis, an important hub of Babylonian foreign trade in the sixth century. Even though the town was located in north-east Babylonia on or near the Tigris, it also functioned as a station of Trans-Euphratian trade. ${ }^{584} \operatorname{In} N b k 361$, a certain Aia-ahâ, son of Šani-Yāma, appears as a party in a court case concerning trade goods or capital (mêreštu) worth $2^{1 / 2}$ minas of silver. ${ }^{585}$ In Neo-Babylonian

\footnotetext{
583 See Waerzeggers 2014b, 140; Abraham 2015, 45, 48.

584 Jursa 2010a, 80-84, 120-121.

585 The document belongs to a group of judicial texts written by Nabû-ahhē-iddin/Šulā/Egibi in Opis, where he - in close contact with people in Prince Neriglissar's retinue - was pursuing a career as court scribe in the late reign of Nebuchadnezzar II. Nabû-ahhē-iddin does not seem to have had any personal interests in this court case, and, as van Driel suggests, the document must have ended up in the Egibi archive because Nabû-ahhē-iddin
} 
business documents, the word mēreštu refers to trade goods that were imported to Babylonia or to silver capital that was invested to acquire such goods. ${ }^{586}$ In the context of the present document, it seems likely that the dispute concerned the capital of a harrānu trading venture, which the investor Nabû-na ${ }^{\text {id }}$ had put at the disposal of his agents Aia-ahâ and Barūhi-il. ${ }^{587}$ Since the word mèreštu belongs to the terminology of long-distance trade and Opis was a starting point for such overland trading missions, it is reasonable to suggest that the venture of Aia-ahâ and Barūhi-il was directed towards an area outside Babylonia proper.

Two other documents on Judean merchants or business agents in Babylonia belong to the archive of the Sipparean trader Iššar-tarībi, son of Bunene-ibni. ${ }^{588}$ Iššar-tarībi's business profile was rather unusual, as he was a non-institutional merchant taking part in long-distance trade. This is indicated by the fact that Opis and the Iranian town of Humaděšu are mentioned in his archive, the latter in a clear trade context. ${ }^{589}$ Iššar-tarībi was a member of the trading community of Sippar ${ }^{590}$ and shared common acquaintances with the descendants of Arih. ${ }^{591}$ Another important feature of Iššar-tarībi's archive is the great number of people with non-Babylonian names, ${ }^{592}$ an element which strengthens the idea that Iššar-tarībi participated in long-distance trade, in which people of foreign origin played a central role.

The first document concerning Judeans in Iššar-tarībi's archive was written in Sippar in the seventh year of Cambyses (26-X-7 Camb, 522 BCE ). ${ }^{593}$ A certain Mannu-kī-Bānītu, son of Bēl-ab-uṣur, sold a donkey to Iššar-tarībi. The contract defines that the donkey was delivered to Mannu-kī-Bānitu by a third

kept copies of some of the documents he wrote in Opis. See van Driel $1985^{-1986,54-59 \text {; }}$ Wunsch 200ob, 98-102; 2007, 237.

586 Oppenheim 1967, 239-240; van Driel 1986, 16-17 + n. 40; Tolini 2009, 249; Jursa 2010a, 93, 505-506.

587 On harrānu partnerships, see Jursa 2009, 53-68; 2010a, 206-214.

588 The texts in the archive of Iššar-tarībi are dated to the second half of the sixth century вСE (8 Cyr-23 Dar). There is no thorough study of Iššar-tarībi and his archive. For short overviews, see Bongenaar 2000, 89-90; Jursa 2005a, 124; 2010a, 220-221, 224-225; Waerzeggers 2014a, 86-89. On his contacts with Judeans, see Waerzeggers 2014b, 140.

589 Dar 149 and Weszeli 1996 no. 2, respectively. See Jursa 2010a, 224-225.

590 Waerzeggers 2014a, 19-22, 86-89.

591 Nabû-iddin/Bānia/Pahhāru witnessed the marriage agreements of Kaššāya and Guzānu, and his nephew Nabû-iqī̌sa is a witness in a promissory note from Iššar-tarībi's archive (unpublished BM 7446o; see Waerzeggers 2014a, 21 n. 33).

592 Il-hanan in Weszeli 1996 no. 2, and Barīkia in Jursa and Weszeli 200o, 82-84, to name but a few. See Zadok 1977, 88, 122-123, respectively.

593 Weszeli 1996 no. 2. 
man called Tagabi-Yāma in Humadēšu. ${ }^{594}$ As Weszeli points out, the scribe obviously made a mistake in the section concerning the delivery of the animal: the recipient of the donkey should naturally be its buyer, Iššar-tarībi. ${ }^{595}$ Humadēšu was not in the vicinity of Sippar, but it was located in Iran, near the site where Persepolis was later built. ${ }^{596}$ There must have been a special reason for a journey to Humadēšu, and in this case, long-distance trade appears to be the most probable explanation. Iššar-taribi was a businessman, and the evidence of a businessman buying a pack animal in a foreign locality points strongly towards trading activities. ${ }^{597}$ Unfortunately, there is no way to know whether Tagabi-Yāma was a servant of the seller or buyer, or their colleague or acquaintance. However, judging from his Yahwistic name, he was a Judean and a man involved in long-distance trade outside Babylonia proper.

In addition to Tagabi-Yāma, another Judean, the son of Gamar-Yāma, is attested in the archive of Iššar-tarïbi. This man, whose name is broken, witnessed a document concerning the sale of a Bactrian female slave. Drafted in Sippar in the tenth year of Darius I (18-II-10 Dar, 512 BCE), 598 this sale contract emphasises the international nature of Iššar-taribi's social circles: none of the witnesses bore a family name, three of them had a non-Babylonian name or patronymic, ${ }^{599}$ and the Bactrian slave had alphabetic writing tattooed or burned on her neck. Tagabi-Yāma and the son of Gamar-Yāma lived in this world of traders, non-Babylonians, and speakers of Aramaic. It cannot be ascertained whether the son of Gamar-Yāma was a merchant himself, but his connection to the circles of Iššar-tarībi is suggestive of such a profile.

\subsection{Conclusion: Long-Distance Trade and Judean Merchants}

It is beyond doubt that some Judeans participated in Babylonian long-distance trade. Tagabi-Yāma's actions in Humadēšu (Iran) took place in an obvious trading context, and all aspects of Aia-ahâ's court case suggest a connection to an overland trading mission. The son of Gamar-Yāma was not perhaps a merchant himself, but he knew people who certainly participated in long-distance trade. In the case of the descendants of Arih, several features of their business activities are indicative of their participation in long-distance trade. Gold had to

594 On the name Tagabi-Yāma, see Zadok 1996, 727.

595 Weszeli 1996, 473.

596 Henkelman 2008, 338.

597 See Zadok 2002, 31; Jursa 2010a, $225+$ n. 1311.

598 Jursa and Weszeli 2000, 82-84.

599 Zadok 2002, 31-32. 
be imported to Babylonia, which means that the family had, at the very least, contacts with people who took part in the importation of the precious metal. Being stationed at Sippar, they were well positioned to either acquire gold from their local contacts or embark on trading missions along the Euphrates. As royal merchants, they belonged to the group of professional traders who undertook such missions to fulfil the needs of the palace, temples, and elite in Babylonia. Finally, people in their social circles in Sippar were involved in local and long-distance trading operations.

It is well known that people of foreign origin played a central role in Babylonian long-distance trade, and it is not surprising that Judeans participated in it as well. The commercial sphere of Babylonian society was open to immigrants, who had some advantages over their Babylonian peers when it came to longdistance trade. One important factor was their ability to reduce the transaction costs of trade: existing networks and knowledge of local languages, products, and trading practices gave immigrants easier access to the markets in their native country. ${ }^{600}$

Judeans participated in Babylonian long-distance trade, and documented evidence shows that some of them travelled as far as Iran for this purpose. There is no evidence that their trading missions reached Syria and the Levant, even though people in their surroundings participated in Trans-Euphratian trade. Judean merchants are attested in Opis and Sippar, which were important stations of trading missions to the west. The descendants of Arih were deeply integrated into the Sipparean trading community, some members of which were involved in trade from Syria and the Levant to Babylonia. Therefore, it is possible that some Judean merchants - such as the descendants of Arih and their colleagues - also travelled to the Levant, perhaps as far as Judah, for the purpose of trade. ${ }^{601}$ This would also make them good candidates for having been intermediaries between Judeans living in Judah and Babylonia. News and messages easily travel along with trade goods over long distances.

6 oo On brokers in cross-cultural trade, see Curtin 1984. On immigration and its impact on modern international trade, see Gould 1994, 302-316; Rauch and Trindade 2002, 116-130; Law et al. 2013, 582-6o6.

601 See Waerzeggers 2014b, 132. 